\title{
Speech Act Taking Place in the Medical Conversation
}

\author{
I Gusti Ayu Agung Dian Susanthi ${ }^{1}$, Ketut Artawa ${ }^{2}$, Ida Bagus Putra Yadnya ${ }^{2} \&$ Made Sri Satyawati $^{2}$ \\ ${ }^{1}$ University of Warmadewa, Bali-Indonesia, Indonesia \\ ${ }^{2}$ University of Udayana, Bali-Indonesia, Indonesia \\ Correspondence: I Gusti Ayu Agung Dian Susanthi, University of Warmadewa, Bali-Indonesia, Indonesia. Tel: \\ 628-1238-577-117. E-mail: gungdian03@gmail.com
}

Received: May 23, 2019; Accepted: June 4, 2019; Published: Jun 12, 2019

\begin{abstract}
This study aims at analyzing the maxims in the five categories of speech act on medical conversation of textbook entitled "English for midwives: Practical Guidance For Antenatal care". The objectives are: (1) To find out the categories of speech act on the medical conversation, (2) To analyze the intended meaning of the speaker, (3) To analyze the cooperative principle that must be concerned on the conversation. There are some theories applied in this study, namely the theory of Speech Act, theory of context of situation, the maxim theory. The result shows that there are three categories of speech act (illocutionary act) found in the conversation, namely: assertive, directives, and expressives. The data (1) shows that the assertive conveys asking information; The data (2) shows directive conveys request; The data (3) shows directive conveys suggestion, there is maxim violation in term of manner found in this data; The data (4) shows directive conveys request; The data (5) shows directive conveys explanation; The data (6) shows directive conveys suggestion, there are maxims violation found in terms of quantity, quality and manner; The data (7) shows expressive conveys asking physiological condition, there are maxims violation in terms of quantity and quality; The data (8) shows expressive conveys asking physiological condition, there are maxims violation in terms of quantity, quality and manner found; The data (9) and (10) show expressives convey asking physiological condition.
\end{abstract}

Keywords: Speech Act, Medical Conversation, Maxim Theory

\section{Introduction}

\subsection{Introduce the Problem}

Language is used by the people to communicate and interact to each other, people use the language in daily life conversation to maintain the social relationship, so that, the purpose of conversation is not only to share information but also to maintain and to build social interaction. In daily life, the conversation is used to get information, asking, giving information, request something, etc. In doing the conversation, there are maxims which need to obey by the speaker.

A maxim may be violated in a conversation or in a text, which leads to awkwardness. This awkwardness could happen when the information given is more than enough, untruthful, irrelevant or too complicated. There are four maxims of conversation, namely: maxim of quality, maxim of quantity, maxim of relevance, and maxim of manner. In conversation, there must be utterance or expression which conveyed by the speaker, this utterance can be analyzed under the theory of Speech Act (Grice, 2001). Speech Act covers three levels, such as: locutionary act, illocutionary force, and perlocutionary effect (Austin 1962, pp. 12), Speech Act can be categorized into five categories namely: assertives, directives, commisive, expressive and declarative (Searle 1976, pp. 1). Those five categories can be used to analyze the intended meaning of the speaker's utterance. In doing the communication, the speaker must also consider "who speaks what language to whom and when", so that in the speaker must also consider the context at time of speaking (Setting, participant, end /goal, art of sequence, key, instrumentalities, and norms). This study takes place on medical conversation, the conversation is between midwife and patient, the conversation must have goal, art of sequence, key, instrumentalities and norms (Hymes 1974, pp. 53-62).

It is known that in health service the midwife must be able to give motivation and suggestion to the patient that makes patient relax and calm. Language in describing motivation, suggestion, giving information, etc. can be found in the medical conversation. However, since there are so many medical terms, the maxims violation in the conversation may occur, since the patient does not have the medical background of knowledge. So that in doing the conversation the midwife must explain the medical terms to the patient, in order to avoid the maxims violation. 
It is interesting to do this research, since there are so many medical terms especially midwifery terms which must be explained by the midwife to the pregnant women so that the patient (pregnant woman) will understand the message and suggestion of the midwife. The textbook as the source is the textbook entitled "English for midwives: Practical Guidance For Antenatal care". This book is chosen, since this book presents the conversation between the midwife and the patient. There are some issues discussed in this study:

(1) What categories of speech act found in the conversation?

(2) What is the intended meaning of the utterance that the speaker wants to convey?

(3) How does the cooperative principles work on the conversation?

\subsection{Importance of the Problem}

It is interesting to explore the medical conversation, because it was found that there were so many medical terms especially midwifery terms which must be explained by the midwife to the pregnant women during the counseling. This research tried to explore the easy way to explain the specific terms to the patient. In relation to the topic discussion of this study, the research was focused on the five categories speech act especially illocutionary act, namely: assertive, directives, commisive, expressive, and declarative. The data source was a textbook "English for Midwives: Practical Guidance for Antenatal care". This study focused on the five categories of illocutionary act, the cooperative principles on the conversation.

\subsection{Relevant Scholarship}

Several works of the scholar focusing on the investigation of maxims was reviewed in this section. To review the relevant works, is important to be done since they are closely related to this study.

Hamadi and Muhammed (2009) in "Pragmatics: Grice's Conversational Maxims Violations in the Responses of Some Western Politicians", this paper accounts for the application of Grice's maxims of conversational implicatures to some political reviews randomly chosen, to serve as objective material of this work. This study is an attempt to find out how much the maxims of quantity, quality, relevance and manner are followed throughout the responses of the politicians con-cerned. Cases of violation are given considerable importance in this paper especially the violation of the maxim of quality which is considered the core of truthfulness of any conversation. The researchers have used statistics and, to some extent, percentages just to show to what extent the above maxims are violated, especially the maxim of quality. The results have proved the correctness of the hypothesis of this work which states that when the maxim of quality is violated, all other maxims are difficult to adhere to.

Jafari (2013) analyzed the verbal behavior of the protagonists of Oscar Wilde's play. 'The importance of being Ernest'. The goal of the research is to investigate the conversations in this literary genre, comedy of manners, from a pragmatic perspective. The analysis covers various pragmatic concepts such as implicature and conversational maxims. The focus of interest is the dyads which create triggers for particular implications in this literary genre. This paper applies Grice's Cooperative Principle to this literary genre to explore which conversational maxims are observed, flouted or violated, and to identify whether the speakers violate the maxims deliberately, unostentatiously or unconsciously. It then illustrates the implicature behind the violated maxim. The results of this study show that in most cases speakers tend to violate the Grice's four maxims of Quality, Manner, Quantity, and Relation respectively, in order to create the intended implicature.

Naeem and Bilal (2013) in their paper "Probing into the Dialogue of the President of Pakistan: Application of Grice's Maxims", this particular work aims at revealing the fact how authoritative people exploit the language to rationalize themselves, and how they could be pointed out by the analysis of spoken discourse following Paul Grice's Cooperative Principle and derived maxims (1975). This study tries to show how political personalities try to defend themselves by collectively using words when appearing in media, in order to promote their ideologies across the public. The mass media analyzes certain issues through the collaboration of the public and tries to expose the grimes of the powerful elites. The researchers have tried to expose how a strong attempt of self-justification has been made by Mr. President. It also advocates how powerful individuals can manipulate language by playing upon words in order to shield themselves. In short, this analysis shows how the speaker molds the language in order to inculcate meanings among the people, thereby, brainwashing them in the attempts of alienation and diversion from what is their actual political agenda.

\section{Method}

This methodology shows how this research was conducted, how the data were collected and analyzed then how the findings were presented. The data were taken from a book entitled "English for Midwives Practical Guidance 
for Antenatal Care" published by Penerbit Buku Kedokteran EGC. This book was chosen because it contains the medical terms and medical conversation which contain the problems presented in this research.

Since it was not conducted in the field, this research was a library research where the data was in the form of documents or printed out texts. Library research is a research that is undertaken in the researcher's room or in the library, where the researcher sets the data and information about his or her objects or research through books or other visual instruments (Semi,1993, pp. 8). The observation was applied by observing thoroughly the conversation. This method was implemented by note-taking technique to collect the relevant data.

The data were analyzed based on classification of problems which mainly focused on the speech act phenomenon and maxims. The method that was implemented in analyzing the data in this study was the qualitative one. In presenting the analyzed data can be drawn by informal and formal method. The former is the method of presenting the analysis by using words to describe the finding while the latter is a presentation of the analyzed data by means of symbols, figures, diagrams as well as table (Sudaryanto, 1993 pp. 145). The researcher may use both a word description and tables to support the data presentation. Firstly, the data was classified into five categories of the illocutionary act, namely assertives, directives, commisives, expressives and declarative in the midwifery conversation, then, the cooperative principles in the midwifery conversation were analyzed.

\section{Results}

This part of discussion presents the analysis of conversation which has certain function which categorized into five categorization of illocutionary act, namely assertives, directives, commisives, expressives and declarative in "English for Midwives Practical Guidance and Antenatal Care". The conversations were analyzed based on the utilized theories namely the theory of speech act, the theory of speech act, meaning and cooperative principle. Thus, in line with the researcher problems, it was mainly concerned with the meaning of the expression which uttered by the speaker (midwife) and patient, as well as to analyze the cooperative principle in the conversation. The analysis as follows:

The Conversation which Conveys Assertives.

Data (1)

On this data shows the midwife explains about the symptoms of pregnancy to her patient.

Patient: Could you tell me what are the signs of pregnancy:

Midwife: Sure..........Vulva, shows blue coloration

Page: 73

The Analysis of Maxims in the Conversation.

Assertive speech act conveys the real or true proposition (Levinson, 1983). For the example, in giving information, giving permission, saying complaint, etc. The speaker usually needs the response from the addressee, in other words the addressee gives the reply based on the speaker need. On the data (1), it is categorized as assertive, since the patient asks the midwife about the symptoms of pregnancy, in asking the information the patient uses the assertive speech act, namely (what?) which aims at asking information. On the above conversation the midwife gives the proper and relevant contribution in explaining the information to the patient, so that the data (1) fulfils the maxims of quantity, quality, and relevance. However, the term Vulva can cause the violation of maxim of manner, if the patient has different background of knowledge (non-medical), since the midwife does not explain the medical term vulva to the patient.

The Conversations which Convey Directives.

Data (2)

On this data the midwife checks the body temperature of the patient

Midwife: Now I would like to check your blood pressure. Please lie down on the examination couch, and roll your right sleeve up. Firstly, I put this thermometer in your left armpit

Patient: Ok.

Page: 48 
Data (3)

On this data the midwife checks the nose of her patient

Midwife : Is there any problem with your nose:

Patient: Yes sometimes I get runny nose especially in the morning

Midwife: You should not take a bath with cool water or drink cool water and eat cool foods that come out from refrigerator

Page: 51

Data (4)

On this data the midwife checks the knee reflex of the patient

Midwife: I'd like to check your knee reflex. Please sit up and swing your legs

Patient: like this, Mam?

Page: 57

Data (5)

On this data shows the conversation between midwife and visitor.

Visitor: I want to see my family in ICU. Could you tell me the way?

Midwife: Oh yes of course. Take this way, go along this corridor .....

Page: 62

Data (6)

On this data the midwife explain about the danger sign pregnancy to the patient

Midwife: Do not forget to remember that you should come immediately if you see emergency signs

Patient: I am afraid, I forgot. Could you tell me again what they are?

Midwife: Yes of course, when there is any vaginal discharge

Patient: Could you tell me the meaning?

Page: 89

The Analysis of Maxims in the Conversation.

A directive is speech act that cause the hearer to take a particular action, e.g request, command, and advice. On the data (2), categorized as directive, since the midwife asks the patient to do something, so that the speech in data (2) has pragmatics functions, namely polite command or requesting the patient to lie down on data (2) and the patient does the midwife's request. On data (2) the midwife would like to check the body temperature of her patient, so she asks the patient to lied down, and the patient lies down as what the midwife's ask. On the above conversation (2) the patient gives the proper and relevant action as the speaker's (midwife) ask, so that the data (2) fulfills the maxims of quantity, quality, relevance and manner.

On the data (3), is categorized as directives, since the midwife suggests the patient not to take a bath with cool water or drink cool water and eat cool foods that come out from refrigerator. In data (3) has pragmatics functions, namely suggestion. The above conversation (3) the midwife gives the clear information and relevant answer as what her patient's need, so in this case this conversation fulfils the maxims of quality, quantity and relevant. However in term of maxim of manner the midwife can give clear information without repeating the word 'cool'.

On the data (4), categorized as directive, since the midwife asks the patient to do something, so that the speech in data (4) has pragmatics functions, namely polite command or requesting the patient to sit up and swing the legs. On the (4) the patient does the midwife's request. On the data (4), the midwife would like to check the knee reflex of her patient, so she asks her patient to sit up and swing the legs, and the patient does the midwife's request. On the above conversation (4) the patient gives the proper and relevant action as the speaker's (midwife) ask, so that the data (4) fulfill the maxims of quantity, quality, relevance and manner.

On the data (5) categorized as directives, since the patient asks the midwife about the way to ICU, so that the speech (question) in data (5) has pragmatics function that is explain or giving information. The speaker (patient) needs certain information and the addresee (midwife) gives the information based on the speaker's need. On the above conversation the midwife gives the proper and relevant contribution in explaining the information to the patient, so that the data (5) fulfils the maxims of quantity, quality, relevance and manner. 
On the data (6), is categorized as directives, since the midwife suggests the patient to come immediately if the patient experiences the emergency sign, so that the midwife's speech in data (6) has pragmatics functions, namely suggestion. On data (6), the patient does not give relevant answer, since she does not understand the meaning of the danger sign itself, so that the patient asks themidwife to explain the meaning of it. So that on the above conversation (6) at the first, the midwife does not give the clear information as what her patient's need, so in this case there is violation in term of maxims of quantity and quality and also manner. However in term of maxim relevance the midwife has given relevant contribution about what is being asked by the patient.

The Conversations Convey Expressives

Data (7)

On this conversation the midwife asks about family health history of the patient
Midwife: Do you have any inherited disease in your family?
Patient: Yes, I have
Page: 41

Data (8) On this data the midwife asks about the condition of the patient during the pregnancy

Midwife: How about your appetite?

Patient: Do you mean nowadays?

Page: 43

Data (9) On this data the patient asks about the condition of the patient during the pregnancy

Midwife: Is your hair thinning?

Patient: I don't think so

Page: 50

Date (10)

\begin{tabular}{l} 
On this data the midwife asks about the menstrual period of her patient \\
\hline Midwife: When was the first day of your mestrual period? \\
Patient: January 16,2007
\end{tabular}
Page: 71

The Analysis of Maxims in the Conversation.

Expressive is speech act that expresses on the speaker's attitudes and emotions toward the proposition, e.g congratulation, excuses, and thanks. This kind of speech act relates to the feeling or emotion which expresses the physichology of the speaker toward the addressee in cerrtain condition (Levinson, 1983). On the data (7), it is categorized as expressive, since the midwife asks the patient about the health history condition of the patient, thus it clearly seen the midwife would like to know condition of the patient. On the data (7) above the patient answers by using relevant answer, so the conversation fulfils the maxims of relevant. However in terms of quantity the patient's answer does not give proper contribution to the midwife, thus the violation in term of maxims of quantity occur. It is also found that there is violation in term of maxims of quality, since the patient does not give clear information to the midwife what kind of inherited disease that she has got.

On the data (8) and (9), are categorized as expressives, since the midwife asks the patient about the appetite and the hair condition of the patient during the pregnancy, thus it is clearly seen the midwife would like to know condition of the patient. On the data (8) above the patient does not answer directly the midwife's question, the patient answer by using question form (do you mean nowadays?) so that the the maxims violation in terms of maxims quantity and quality, since the patient does not give direct answer and also maxim of relevance, since the patient does not give the relevant answer.

On the data (10), it is categorized as expressive, since the midwife asks the patient about the patient's condition, in this case the patient's menstrual period, thus it clearly seen the midwife would like to know condition of the 
patient. On the data (10) above the patient answers by using relevant, clear contribution, so the conversation fulfils the maxims of quantity, quality, relevant and manner.

\section{Discussion}

Based on the explanation on the previous sessions there are some points can be viewed:

1. There are three categories of speech act (illocutionary act) found in the conversation, namely: Assertive, directives, and expressives.

2. The data (1) shows that the assertive conveys asking information.

The data (2) shows directive conveys request.

The data (3) shows directive conveys suggestion, there is maxim violation in term of manner found in this data.

The data (4) shows directive conveys request.

The data (5) shows directive conveys explanation.

The data (6) shows directive conveys suggestion, there are maxims violation found in terms of quantity, quality and manner.

The data (7) shows expressive conveys asking physical condition, there are maxims violation in terms of quantity and quality.

The data (8) shows expressive conveys asking physical condition, there are maxims violation in terms of quantity, quality and manner found.

The data (9) and (10) show expressives convey asking physical condition.

\section{Acknowledgments}

The researcher would like to thank to those who have given contribution during the writing of this research so that this article can befinished, my deepest thankful is dedicated to the board of examiners: Prof. Dr. Made Budiarsa, M.A., Dr. Ida Ayu Made Puspani, M.Hum., Dr. Dra. Ni Wayan Sukarini, M.Hum., and Prof. Dr. I Nyoman Kardana, M.Hum., for the support, suggestion during the writing of this research.

\section{References}

Austin, J. L. (1962). How to do things with words. New York: Oxford University.

Bloomfield, L. (1995). Language. Jakarta: Gramedia.

Chaer, A. (2007). Linguistik Umum. Jakarta: Rineka Cipta.

Hamadi, \& Muhammed (2009). Pragmatics: Grice's Conversational Maxims Violations in the Responses of Some Western Politicians. Journal of the College of Arts. Universtity of Basrah, No. (50).

Jafari, J. (2013). The Pragmatic Analysis of Wilde's Comedy: The Importance of Being Ernest. Journal of Theory and Practice in Language Studies, 3(12), 2151-2156. https://doi.org/10.4304/tpls.3.12.2151-2156

Kridalaksana, H. (2007). Pembentukan Kata dalam Bahasa Indonesia, $4^{\text {th }}$ ed. Jakarta: Gramedia Pustaka Utama.

Leech, G. N. (1983). Principles of Prgamatics. London: Longman.

Levinson, S. C. (1983). Pragmatics. Cambridge: CUP. https://doi.org/10.1017/CBO9780511813313

Louise, C. (2007). Pragmatik: Sebuah Perspektif Multidisipliner. Pustaka Belajar.

Nababan, P. W. J. (1987). Ilmu Pragmatik (Teori dan Penerapnannya). Jakarta: Departemen Pendidikan dan Kebudayaan.

Naeem, \& Bilal (2013). Probing into the Dialogue of the President of pakistan: Application of Grice's Maxims. International Journal of Linguistics, 5(4). https://doi.org/10.5296/ijl.v5i4.4157

Ross, A. (1998). Language of Humour. Routledge.

Verhaar, J. W. M. (2008). Asas-asas Linguistik Umum. Yogyakarta: Gajah Mada University.

Wahab, A. (1995). Teori Semantik.Surabaya: Airlangga University Press.

Widaningsih, I. (2009). English For Midwives Practical Guidance For Antenatal Care. Jakarta: EGC.

Wijana, D. P. (1996). Dasar-dasar Pragmatik. Yogyakarta: Andi offset.

Winson, \& McDonald (2005). Kamus Kebidanan Bergambar. Jakarta: EGC Medical Publisher. 
Yule, G. (1966). Syntax, Semantics and Pragmatics. Oxford: Oxford University Press.

\section{Copyrights}

Copyright for this article is retained by the author(s), with first publication rights granted to the journal.

This is an open-access article distributed under the terms and conditions of the Creative Commons Attribution license (http://creativecommons.org/licenses/by/4.0/). 